\title{
Correction to: Atomic-Scale Analysis of Oxide Inclusion in Weld Metal Using Atom Probe Tomography
}

\author{
JUN TAKAHASHI, YUJI KISAKA, KAZUTO KAWAKAMI, \\ and HIDENORI TERASAKI
}

https://doi.org/10.1007/s11661-022-06638-w

(C) The Minerals, Metals \& Materials Society and ASM International 2022

Correction to: Metallurgical and Materials Transactions A https://doi.org/10.1007/s11661-022-06623-3

IN the original online version of this article Hidenori Terasaki's given name was spelled incorrectly. The Publisher's Note Springer Nature remains neutral with regard to jurisdictional claims in published maps and institutional affiliations.

JUN TAKAHASHI is with the Advanced Technology Research Labs, Nippon Steel Corporation, 20-1 Shintomi, Futtsu, Chiba 2938511, Japan. Contact e-mail: takahashi.3ct.jun@jp.nipponsteel.com YUJI KISAKA is with the Engineering R\&D Institute, Nippon Steel Engineering Co., Ltd., 46-59 Nakabaru, Tobata-ward, Kitakyusyu, Fukuoka 804-8505, Japan. KAZUTO KAWAKAMI is with the Resource and Process Solution Dev., Nippon Steel Technology Co. Ltd., 20-1 Shintomi, Futtsu, Chiba 293-0011, Japan. HIDENORI TERASAKI is with the Faculty of Advanced Science and Technology, Kumamoto University, 2-39-1 Kurokami, Chuo-ward, Kumamoto, Kumamoto 860-8555, Japan.

The original article can be found online at https://doi.org/10.1007/ s11661-022-06623-3.

Article published online March 1, 2022 